\title{
Anna Barańska-Szmitko*
}

(iD https://orcid.org/0000-0002-0359-0638

\section{The impact of a YouTuber's lively gesticulation on his image The case of Wojtek Drewniak and his Historia bez cenzury}

\section{Introduction}

The aim of this article is to define, based on selected research material, the impact on image-based communication of the gesticulation in a popular science historical discourse fulfilled on YouTube. In that respect I shall analyse the image of Wojtek Drewniak ${ }^{1}$, the host of the Historia bez cenzury [History uncensored] channel.

Based on the literature of the subject one may conclude that gesticulation and, more broadly speaking, body language are studied by researchers from various fields. Cultural studies scholars, sociologists, psychologists, and linguists (working alone or in interdisciplinary teams) often focus on the cultural foundations of gestures and try to indicate the similarities and differences between cultures. For example, Agnieszka Szczepaniak has focused on body language (limited to the so-called emblematic gestures) of Poles, Greeks and the British. ${ }^{2}$ Francois Caradec prepared a dictionary of gestures typical for the French but he also included in it,

* Ph.D., University of Lodz, Faculty of Philology, Chair of Communication Theory and Practice, Department of Journalism and Social Communication; e-mail: anna.baranska@filologia.uni. lodz.pl

1 The caption identifying the host features this particular diminutive form of his name.

2 A. Szczepaniak, Gesty emblematyczne w międzykulturowej komunikacji niewerbalnej. Polskogrecko-brytyjskie studium porównawcze i gestownik, Kaliskie Towarzystwo Przyjaciół Nauki, Uniwersytet Wrocławski, SWPS Uniwersytet Humanistyczno-Społeczny, Kalisz-Wrocław 2017. 
e.g. Indians, the Japanese and the representatives of Arabic cultures. ${ }^{3}$ Krystyna Jarząbek developed Słownik mowy ciała Polaków [Dictionary of the Body Language of Poles]. ${ }^{4}$ There are also works which emphasise the relationship between natural language ${ }^{5}$ and body language or which argue that body language is a system just as complex as the natural language. ${ }^{6}$ The main characteristic of those is the focus on gestures and their communicational functions.

However, sometimes the direction of an analysis is reverse; researchers are interested in a certain aspect of human communicational activities in which they see a specific role of non-verbal communication. Amongst such a topic one should list the issue of detecting/ communicating lies ${ }^{7}$, behaviour during job interviews ${ }^{8}$, and, most of all, the use of body language by politicians. ${ }^{9}$ The image aspect appears

3 F. Caradec, Dictionary of Gestures. Expressive Comportments and Movements in Use around the World, illustrated by P. Cousin, trans. Chris Clarke, The MIT Press, Cambridge, Massachusetts, London 2018.

4 K. Jarząbek, Słownik mowy ciała Polaków, Wydawnictwo Uniwersytetu Śląskiego, Katowice 2016.

5 A. Cienki, C. Müller, Metaphor and Gesture, John Benjamin Publishing Company, AmsterdamPhiladelphia, 2010.

6 N. Rossini, Reinterpreting Gestures as Language. Language "in Action", IOS Press, AmsterdamBerlin-Tokyo-Washington DC 2012.

7 Vide, e.g. J. Antas, O kłamstwie i kłamaniu, Universitas, Krakow 2008. Also: D.G. Leathers, "Wykrywanie oszustwa", [in:] Komunikacja niewerbalna. Zasady i zastosowania, trans. M. Trzcińska, ed. Z. Nęcki, Wydawnictwo Naukowe PWN, Warsaw 2009, pp. 299-324. Or: W. Sikorski, "Gesty kłamstwa", [in:] ibidem, Niewerbalna komunikacja interpersonalna. Doskonalenie przez trening, 2nd ed., Difin, Warsaw 2018, pp. 204-212.

8 Vide, e.g. W. Sikorski, "Komunikacja niewerbalna podczas rozmowy kwalifikacyjnej", [in:] Niewerbalna komunikacja interpersonalna. Doskonalenie przez trening, pp. 128-156, or: D.G. Leathers, "Rozmowa kwalifikacyjna", [in:] Komunikacja niewerbalna. Zasady i zastosowania, pp. 345-352. I am omitting a whole host of guidelines and advice on the topic included in numerous handbooks on self-presentation or creating one's image in business, which are based on the same studies (if those are recommendations somehow related to academic studies).

9 Some more significant texts in the extensive subject literature include, e.g. J. Antas, M. Kozień, "Gesty i rytuały niewerbalne oraz ich znaczenie w obecnej polityce polskiej", Acta Universitatis Lodziensis. Folia Litteraria Polonica 2018, issue 2(48), pp. 113-128; ks J. Szymczyk., "Funkcje mowy ciała w procesie kreowania wizerunku publicznego polityków", Roczniki Nauk Społecznych 2018, vol. 10(46), no. 2, pp. 131-161; J. Antas, A. Załazińska, "Niewerbalne środki i strategie przekonywania stosowane w telewizyjnych debatach polityków", [in:] Sztuka perswazji. Socjologiczne, psychologiczne i lingwistyczne aspekty komunikowania perswazyjnego, eds. R. Garpiel, K. Leszczyńska, Wydawnictwo „Nomos”, Krakow 2008, pp. 183-194; W. Sikorski, "Tworzenie pozytywnego wrażenia w polityce", [in:] Niewerbalna komunikacja interpersonalna. Doskonalenie przez trening, pp. 156-185; D.G. Leathers, "Zarzadzanie wrażeniem w praktyce", [in:] 
only in the context of the media behaviour of politicians, and mind you: that is a rather peculiar mode of communication. Specific reactions and gestures of public figures carry particular significance as they are recorded (be it on video or in photos) and later (or simultaneously) they appear in the media and they exert a major impact on the perceptions of politicians which voters formulate based on such communications.

Clearly, it would be difficult to transfer the results of such studies and analyses to a study of significance of gesticulation for a YouTuber, for whom verbal communication is most important, sometimes only enriched with visual or audio material. Furthermore, one should note that among all YouTubers there are media dabblers, i.e. persons who often possess specific knowledge yet lack any training in public speaking. In that respect their communicational conduct is natural. That quality together with their universality are noteworthy particularly since the content published on YouTube channels gathers new audiences and there is still no subject literature on the relationship between gesticulation of show hosts and their image.

\section{Theoretical perspective}

I decided to employ the theoretical framework of Michael Fleischer's rational constructivism according to which the reality known to us is the result of an act of construction conducted by an interpreter, who perceives the physical reality (first reality) through senses (second reality) and assigns to it meaning using signs, where the third stage is conducted using communication (third reality). An interpreter participates in a social system and, at the same time, receives sign-based objects ${ }^{10}$, whereas the same signs may function in various systems (e.g. visual, auditory, verbal) and form the expressions of an author which the interpreter, i.e. the recipient of the expression, may use as the basis for constructing the image of the author.

Komunikacja niewerbalna. Zasady i zastosowania, pp. 254-264; I. Íñigo-Mora, G. Álvarez-Benito, "Gestures and words in political discourse: a case study of the Obama-McCain encounter", Respectus Philologicus 2010, issue 18(23), pp. 11-25; A. Boniecki, "Pozajęzykowe środki kreowania wizerunku polityka", [in:] Język w komunikacji, ed. G. Markowski, Wydawnictwo im. Stanisława Podobińskiego Akademii im. Jana Długosza w Częstochowie, Częstochowa 2011, pp. 31-42; A. Majkowska, "O komunikowaniu parawerbalnym i niewerbalnym w dyskusji sejmowej", [in:] Język w komunikacji, ed. G. Markowski, Wydawnictwo im. Stanisława Podobińskiego Akademii im. Jana Długosza w Częstochowie, Częstochowa 2011, pp. 21-29; A. Komendarczyk, "Pozawerbalna ekspresja polityków w debacie telewizyjnej", [in:] Język w komunikacji, ed. G. Markowski, Wydawnictwo im. Stanisława Podobińskiego Akademii im. Jana Długosza w Częstochowie, Częstochowa 2011, pp. 43-53.

10 Vide a broader discussion of those relationships in: M. Fleischer, „Rozsądny konstruktywizm”, [in:] ibidem, Ogólna teoria komunikacji, Wydawnictwo Uniwersytetu Wrocławskiego, Wrocław 2007, pp. 86-173. 
That is also the case when it comes to the image of a YouTuber, which is the product of an act of construction conducted by an interpreter after watching an expression by the YouTuber, which is fulfilled through several systems of signs.

One should also note, in this context, the useful division into speaking and communicating. Michael Fleischer stressed that "while speaking applies to that which is spoken, communicating applies to how it is spoken and what is communicated by what and how one says something."11 In other words, one could boast that one is a specialist in the literature of Spanish Enlightenment and values particularly highly the achievements of Saint Augustine, its leading poet, mainly for introducing innovative narrative solutions in his greatest play Hamlet. What one said was nothing more than what the words stand for, yet what one communicated was a deep ignorance in terms of the history of literature.

The issue is particularly important in the discussed study of a YouTuber's image as the analysis will apply to the level of communicating not speaking, meaning it will define the image of the YouTuber and the significance of the gesticulation of the author of the expression for his image. Neither the YouTuber's intentions nor what he said constitute the focus of the analysis. What is important is what an interpreter constructs based on a clip and what the impact of the gesticulation is.

For clarity, allow me to define how I understand gesticulation. It covers the motions of one or several parts of the body, and in terms of human expression the majority of gestures applies to arms and the head ${ }^{\mathbf{1 2}}$, and the biggest number of typologies apply to those parts of the body. This study omits facial expressions, communication with eyesight, proxemics and haptics. ${ }^{13} \mathrm{~W}$ hen presenting historical content, Wojtek Drewniak is present on the screen more or less from the waist up, which means that in this case gestures must apply mostly to arms and the head, which was in fact mainly indicated by the study subjects.

\section{Method and study procedure}

I utilised the experiment formula and applied it to one study group. After watching one video of Historia bez cenzury, the subjects answered the question: "Based on the episode of Historia bez cenzury you have just watched, how would you describe Wojtek Drewniak?" Next, the subjects were asked the following: "For each quality

11 M. Fleischer, Typologia komunikacji, Primum Verbum, Łódź 2012, p. 29 [unless indicated otherwise, quotations in English were translated from Polish].

12 A. Szczepaniak, p. 16.

13 Vide the clear textbook division of body language in: T.G. Grove, "Niewerbalne elementy interakcji", [in:] Mosty zamiast murów. Podręcznik komunikacji interpersonalnej, ed. J. Steward, trans. J. Suchecki, P. Kostyło, J. Kowalczewska et al., 4th ed., Wydawnictwo Naukowe PWN, Warsaw 2005, pp. 122-134. 
you specified for Wojtek Drewniak, please provide words, sentences or fragments of his statements and/or behaviour, gestures, facial expressions, etc. and/or sound/ visual elements of the video which were the reason why you assigned the quality." The first task was intended to extract image-related qualities, while the other to indicate the communicational indicators of each quality. ${ }^{14}$

The study subjects watched two videos from the channel. One described a battle: "Lomot po polsku \#2 - Husaria pod Kircholmem" (67 persons), the other was of a biographical type: "Mózg na wypasie - Albert Einstein" (24 persons). ${ }^{15}$ The duration of each one was approx. 17 minutes. The whole study took no more than 25-30 minutes.

As the study focuses on the YouTuber Wojtek Drewniak who provides historical content, i.e. by listing dates, names, places and, sometimes, terms or words which might be considered as specialised, then the image of an expert might have formed. At the same time, the high level of "commonalisation" of the content being communicated (the popular science style/discourse ${ }^{16}$ ) lifts the air of exclusivity off his videos making them accessible and enjoyable thus seizing the audience's attention. Originally, I used the study to check what kind of impact colloquialisms had on the historian's image of an expert, but the major significance of the YouTuber's gesticulation made the issue important enough to be worthy of a separate study. At that point I assumed, which was later disproved by the results, that the communication of the content and not the gesticulation constituted the foundation of the historian's image. Therefore, it seems even more important to closely analyse the matter and its relationship with image-building.

The study was conducted on 28 February and 1 March 2019 among 91 1st-year students of journalism and social communication at the University of Lodz. I intentionally approached students of humanities as I assumed they were more eloquent and skilled in articulating their thoughts than students of other focuses. I decided not to approach students of later years as they are too aware of styles, rhetoric devices and journalistic genres, which could have negatively impacted the results. ${ }^{17}$ Before the students decided to participate in the study, I instructed them on its voluntary and anonymous nature.

14 Task sheets were of an A5 format. Underneath each instruction, there were five bullet points which suggested the number of qualities to be indicated; that was intended to ensure comparability of the results.

15 The disproportion was mainly a result of the sizes of groups and class attendance.

16 To read more on mixing the notional extents of style and discourse vide S. Gajda, "Teoria stylu i stylistyka", [in:] Style współczesnej polszczyzny. Przewodnik po stylistyce polskiej, eds. E. Malinowska, J. Nocoń, U. Żydek-Bednarczuk, Universitas, Krakow 2013, pp. 15-33.

17 2nd-year students were acceptable but a sufficient number of subjects enabled me to refrain from expanding the study group to include other years. 


\section{The results}

The following table summarised the main preliminary details of the analysed results. The resulting study material had the form of 436 characteristics (instruction 1) listed by the study subjects and notes indicating the communicational basis (instruction 2) of those characteristics. The so-called open coding ${ }^{18}$ enabled me to classify the qualities listed by the subjects under 25 consistent image characteristics, e.g. "energiczny" (energetic), "zabawny" (funny), "ciekawie opowiada" (talks in an interesting way), "pasjonat" (enthusiast), "inteligentny" (intelligent), "charyzmatyczny" (charismatic), "sympatyczny" (friendly), "nieśmieszny” (unfunny), etc. ${ }^{19}$ The study subjects indicated various manners of communicating image characteristics. For example, he appeared educated to some study subjects because he quoted various details or cited books. To some subjects the historian seemed "bezpośredni" (direct) because, e.g. he used colloquialisms and avoided euphemisms, while his smile or jokes were the basic elements of communicating the characteristic of "sympatyczny" (friendly). Lively gesticulation was also among the various manners of communicating various image characteristics. It was indicated 83 times which considering the total number of indications (436) constituted slightly over $19 \%$ of all indications. Those 83 indications of gesticulation as the basis for communicating an image characteristic appeared among 10 (out of 25) indicators of image characteristics. 63 subjects listed gesticulation as the indicator of a specific characteristic(s), i.e. $69.23 \%$ of all study subjects.

Table 1. Summary of results for gesticulation when compared to all indications regarding Wojtek Drewniak.

\begin{tabular}{|l|c|}
\hline Data category & Number \\
\hline All indications & 436 \\
\hline All characteristics & 25 \\
\hline Indications to gesticulation & 83 \\
\hline$\%$ of indications regarding gesticulation in reference to the whole & $19.04 \%$ \\
\hline
\end{tabular}

18 The classification and references to notion "based on direct insight into data and the detailed analysis of it" after: E. Babbie, Badania społeczne w praktyce, Wydawnictwo Naukowe PWN, Warsaw 2004, pp. 626-627, vide also: G. Gibbs, Analizowanie danych jakościowych, trans. M. Brzozowska-Brywczyńska, series: Niezbędnik Badacza, Warsaw 2011, p. 91.

19 Other image characteristics assigned by the subjects included: "ma wiedzę" (he is knowledgeable), "kreatywny" (creative), "bardzo gestykulujący" (gesticulates a lot), "pozytywny" (positive), "wygadany" (voluble), "irytujący" (irritating), "szalony" (mad), "pewny siebie" (self-confident), "profesjonalista" (professionalist), "wykształcony" (educated), "głośny" (loud), "chaotyczny" (chaotic), "wyluzowany" (chill), "elokwentny" (eloquent), "ekscentryczny" (excentric), "bezpośredni" (direct). 


\begin{tabular}{|l|c|}
\hline Data category & Number \\
\hline Characteristics communicated i.e. using gesticulation & 10 \\
\hline People who indicated gesticulation as an indicator of a characteristic & 63 \\
\hline$\%$ of people who indicated gesticulation as the indicator of image characteristics & $69.23 \%$ \\
\hline
\end{tabular}

Source: own study.

This compilation indicates how important gesticulation is for one's image. Nearly one in five of all references to the motions of arms and the head and over two in three study subjects considered that aspect of non-verbal communication as the basis of assigning specific image characteristics.

Image characteristics assigned by study subjects based on lively arm or head motions included: "energiczny" (energetic), "pasjonat" (enthusiast), "charyzmatyczny" (charismatic), "o wyrazistej mowie ciała" (with expressive body language), "ciekawie opowiada" (talks in an interesting manner), "chaotyczny" (chaotic), "szalony" (mad), "irytujący" (irritating), "pewny siebie" (self-confident), and "wyluzowany" (chill).

Most often, lively gesticulation triggered subjects to assign the characteristic of "energiczny" (energetic). That applied to 49 in 83 instances (i.e. 59.04\%), and a total of 43 in $63(68.25 \%)$ subjects saw that quality in Wojtek Drewniak based on his movements. ${ }^{20}$

$\mathrm{NB}$, instances of gesticulation as isolated indicators were very rarely related to the historian's energy - only eight of the case study subjects indicated it in isolation writing, e.g.:

- ciągła gestykulacja podczas opowiadania ${ }^{21}$ (unrelenting gesticulation while talking);

- duża, gęsta gestykulacja (extensive, thick gesticulation);

- gestykulacja rękami przez cały czas (gesticulation with arms all the time).

In the remaining cases, what was important was the co-occurrence of noticeable vivid gesticulation with pace and/or tone, with facial expressions, with both

20 The difference in the number of people and the number of indications was caused by the fact. That sometimes the same people indicated the same characteristics twice or more times only referring to it differently. In such cases, despite two different determinations (e.g. "energiczny" (energetic) or "ekspresywny" (expressive)) a specific characteristic was classified under one image characteristic ("energiczny"), which numerically resulted in two indications related to only one subject.

21 All quoted remarks by study subjects are in original form, without any changes to the answers on the survey form. 
elements simultaneously, and, finally, with the movements of the entire body or other aspects of non-verbal communication.

The most common indications ( 16 in total) referred to gesticulation, which determined the energetic quality in combination with pace and/or tone. The study subjects indicated, e.g.:

- pojawiało się dużo ruchu (np. rękami), ton głosu pozbawiony był swego rodzaju monotonii, dlatego nie dało się nudzić [there was a lot of movement (e.g. arms), tone of voice was devoid of the typical monotony so it was impossible to be bored];

- bogata gestykulacja podczas trwania całego programu (praca rak, głowy), sposób opowiadania bardzo żywy [rich gesticulation throughout the show (arms, head), very vivid mode of talking];

- mówi w sposób energiczny oraz dużo gestykuluje [he speaks in an energetic manner and gesticulates a lot].

Half as many indications (8) referred to the characteristic of "energiczny" (energetic) communicated using gesticulation together with facial expressions. The subjects thus wrote about that:

- gesty, mimika - gesty bardzo szybko następowały po sobie, wraz z nimi zmieniała się mimika prowadzacego [gestures, facial expressions - gestures occurred rapidly one after the other, the host's facial expressions changed along them];

- mowa ciała/mimika [body language/ facial expressions];

- gesty, bogata mimika [gestures, rich facial expressions].

For 7 people, gesticulation was noticeable together with the voice and facial expressions:

- szybka gestykulacja, bogata mimika twarzy, ton i barwa głosu [rapid gesticulation, rich facial expressions, tone and timbre];

- dużo gestykulował, jego mimika twarzy ciagle się zmieniała, mówił dość szyb$k o$ [he gesticulated a lot, his facial expressions constantly changed, he spoke quite quickly];

- mówi różnymi tonacjami, używa dużej ilości gestów, mimiki [he speaks in different pitches, he uses many gestures, facial expressions].

Finally, also 7 subjects viewed the movements of mainly arms as functioning together with the movements of the entire body, as indicated in the remarks:

- szybkie ruchy dłonmi, poruszanie ciałem [rapid hand motions, body movements];

- skoki, ruchy rękoma [jumps, arm movements];

- cały czas wykonywat dużo gestów, praktycznie podskakiwat, nie potrafi ustać $w$ miejscu [he constantly made a lot of gestures, he was practically jumping, he could not stand still]. 
Three subjects indicated the combination of gesticulation with other aspects of human communication.

In summing up the communication of the "energiczny" (energetic) characteristic, one should conclude that it was significant in half of the indications among which it functioned independently as the indicator of the discussed characteristic in only 8 instances, while it co-occurred with other aspects of body language in 41 indications. Interestingly enough, if one was to consider other communicational indicators of "energiczny" (energetic), those would include mainly a high pace of speaking, i.e. mainly extra-verbal elements constructing the image-related characteristic.

Other image-related characteristics communicated using, e.g. gesticulation, were to a much lesser extent based on it.

The "charyzmatyczny" (charismatic) characteristic throughout the study was assigned 15 times out of which in 7 instances it was associated with gestures. Arm movements together with facial expressions and/or pace of speaking were decisive in four indications, while in the remaining three for the first time some role was played by verbal elements (e.g. ładne i rozbudowane zdania, plynność mowy, gesty podkreślajace słowa [nice developed sentences, fluent speech, gestures emphasising the words]). Apart from indications of gesticulation there was one indication of facial expressions, one of voice, and two of self-confidence; in the remaining cases less precise indications were decisive by the study subjects (e.g. Cały film, wypowiedzi o tym świadcza [The entire video, statements indicate that]). Despite the communication of charisma, non-verbal communication was largely important ( 9 in 15 indications), it was still a characteristic which was rather difficult to describe for the subjects.

In the case of the "pasjonat" (enthusiast) characteristic, solely gesticulation as the communicational indicator of the characteristic (e.g. gestykuluje bardzo duzo [gesticulates a lot]) was indicated twice; in other three cases facial expressions were also indicated (widać to po jego mimice, gestach [that is visible in his facial expressions, gestures]), and in one, several different co-occurring instances of behaviour related to body language (Po prostu czuć $i$ widać, że Wojtek bardzo interesuje się historią. Uśmiech przy opisywanych wydarzeniach, żywa gestykulacja, podniesiony głos, wreszcie mówienie, bez choćby jednego zajęknięcia potęgują owe przekonanie" [You can simply feel and see that Wojtek is very much interested in history. Smiles while discussing events, vivid gesticulation, raised voice, finally speaking without even one stutter emphasises the conviction]).

Study subjects assigned this image-related characteristic to Wojtek Drewniak 36 times, out of which only 10 indications referred to his knowledge as the basis for associating him with "passion", 6 times gesticulation was important, and in the remaining 20 instances other elements of extra-verbal communication were the basis of communication, mainly high pace of speaking. 
The image-related characteristic of "o wyrazistej mowie ciała" [with a vivid body language] was based on gesticulation itself in three instances (e.g. Kiedy tylko nie miał ksiązki $w$ rękach, to nie przestawat nimi machać [Whenever he didn't have a book in his hands, he waved them incessantly]), in another three there was also other aspects of non-verbal communication (e.g. podczas ogladania filmu w oczy rzuciły mi się bardzo jego gesty, ruszanie rękoma, głowa, oczami [while I was watching the video, what was striking were his movements, his moving arms, head, and eyes]).

The historian "ciekawie opowiada" [talked in an interesting manner] in 36 cases, out of which four depended on gesticulation and only when it functioned together with the appropriate pace of simple narration. For example:

- nie mówi wolno, jest $\dot{z} y w y$, mówi prostym językiem oraz dużo obrazuje [he does not talk slowly, he is lively, he talks in simple language and with much imagery];

- interesujacy ze względu na gesty, które wykonuje oraz głos, który według mnie przyjemnie się stucha [interesting considering his gestures which he makes and his voice which according to me is pleasant to listen to].

Apart from that visual additions ( 2 indications) had minor significance. Mainly, though, Wojtek Drewniak potrafi w interesujacy sposób przekazać informacje [can convey information in an interesting way] or całość przyjemnie się słuchało [it is pleasant to listen to the whole], etc., i.e. the task of specifying the basis of assigning the characteristic posed some problems for the study subjects.

The "chaotyczny" [chaotic] characteristic was associated with gesticulation three times. Apart from arm movements (once - wnioskuje po jego gestykulacji (machanie rękoma) [I gather based on his gesticulation (waving his arms)]) subjects indicated twice the set of non-verbal aspects (Mówił dość szybko, dużo gestykulował $i$ ciagle się poruszat [He talked rather quickly, he gesticulated a lot and moved constantly]). In total, it was recorded 6 times. Decisive in assigning it was also the frequent and rapid changes of topic, which confused recipients.

The characteristic of "szalony" [mad] was assigned a total of 11 times, out of which gesticulation was indicated three times as the method of communicating it, every time łącznie $\mathbf{z}$ mimiką i/lub tempem głosu [together with facial expressions and/or speaking pace] (e.g. ożywiona mimika i gesty, szybkie tempo mowy [vivid facial expressions and gestures, high-paced speech]). It was the voice and facial expressions, especially the protruding stare, that were the main (6 times) basis for assigning the characteristic. In the remaining two cases, linguistic aspects gained significance (puns).

Wojtek Drewniak was "irytujący" [irritating] (10 times throughout the study) because he gestykuluje głośno i szybko mówi [gesticulates loudly and talks 
quickly] ( 2 times), though for the characteristic to be assigned, the voice was enough ( 5 indications) or graphic additions (2 times) or other forms of communication (1).

"Pewność siebie" [self-confidence] ( 9 indications in total) was the domena gestykulacji i pewnego głosu [domain of gesticulation and steadfast voice] ( 2 indications), but also steadfast voice alone sufficed (3 indications), looking straight into the camera (2) or other aspects (2).

"Wyluzowanie" [chill] only once depended on gesticulation (Wyluzowany, ponieważjego ruchy, gestykulacja byłabardzopłynna iniezaburzała wypowiadanych przez niego słów [He's chill because his movements, gesticulation were very fluid and did not distort the words he uttered]). The remaining indications (5) focussed on colloquial language and/or puns.

\section{Summary and conclusions}

In summary, and in conclusion, allow me to use the following synthesis in the form of a table. The table cells which apply to "gesticulation among the characteristics communicated through it" include data regarding only gesticulation. The table cells which refer to "individual characteristics among all characteristics" include data in the context of all indications of a given image-related characteristic, not only in reference to gesticulation.

Clearly, based on gesticulation the historian was most often assigned the characteristic of energetic (59\% indications regarding gesticulation, nearly $50 \%$ of the study subjects associated it with Wojtek Drewniak). In the case of other characteristics, gestures played at least a 7-time less important role. The "charyzmatyczny" [charismatic] characteristic was assigned only 7 times, "pasjonat" [enthusiast], "o wyrazistej mowie ciała" [with a vivid body language] 6 times, "ciekawie opowiada" [talks in an interesting manner] 4 times, "chaotyczny" [chaotic], "szalony" [mad], "irytujący" [irritating] 3 times, "pewny siebie" [selfconfident] 2 twice, and "wyluzowany" [chill] only once. 


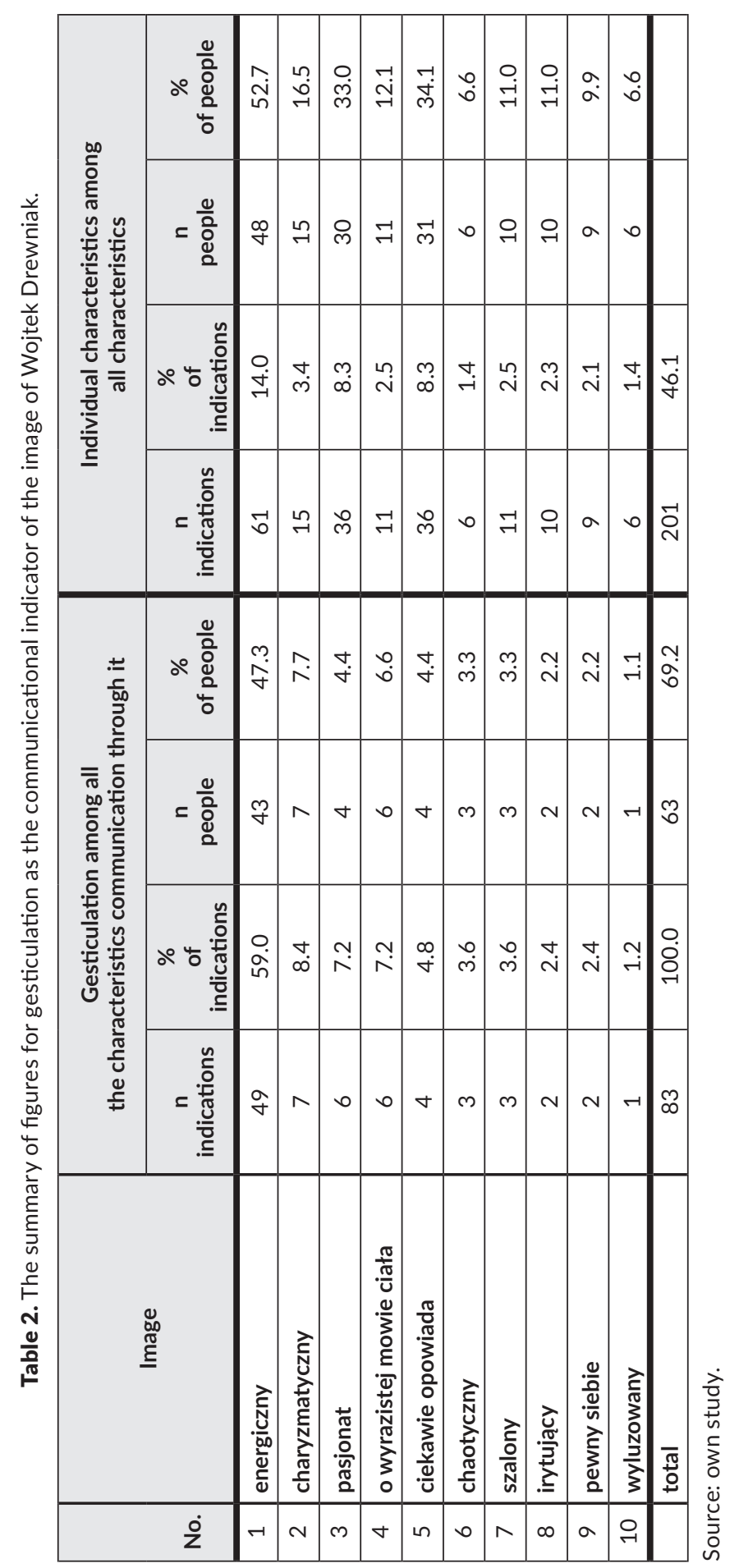


The communication of the listed image-related characteristics is conducted not only by gesticulation but also by other aspects of extra-verbal communication. It is very often the case that gestures become the basis of assigning the designations together with other elements of body language. Gesticulation and high-paced speaking was particularly significant for the characteristics of "irytujący" [irritating] and "pewny siebie" [confident], "ciekawie opowiada" [talks in an interesting manner], and "pasjonat" [enthusiast]. In the case of "energiczny" [energetic], "charyzmatyczny" [charismatic], "o wirazistej mowie ciała" [with a vivid body language], "chaotyczny" [chaotic], apart from the vocal elements, the study subjects also indicated lively facial expressions, and for the "szalony" [mad] characteristic what was decisive was protruding eyes.

Only some characteristics included among their indicators methods of communication based on verbal communication, e.g. subjects associated with the construction of neat sentences containing "charyzma" [charisma], references to data which indicates knowledge as being "pasjonat" [enthusiast], understandable manner of conveying content indicated that the historian "ciekawie opowiada" [talked in an interesting manner], the use of jokes was supposed to indicate in some cases the communication of the characteristic of "szalony" [mad], many changes in the direction that the talk took indicated the characteristic of "chaotyczny" [chaotic], and the use of colloquial speech indicated the characteristic of "wyluzowany" [chill].

Interestingly enough, the movements made by Wojtek Drewniak in addition to the characteristics which seem obvious in the case of body language and image (e.g. "energiczny" [energetic], "o wyrazistej mowie ciała" [with an expressive body language]), they also communicated characteristics which were closer to the mode of verbal expression ("ciekawie opowiada" [talks in an interesting manner], "charyzmatyczny" [charismatic], "pasjonat" [enthusiast]). That might indicate extensive extra-verbal communication opportunities and its broad combinations with characteristics not close to body language.

Please note that Wojtek Drewniak's gesticulation most often (as indicated by the study subjects) consisted of waving his arms, high-paced talking, confident speech, with clear articulation, changing the pace and sometimes tone. Subjects indicated facial expressions, but when they became more specific, they usually indicated protruding eyes.

All of that indicates vivid body language, which, of course, cannot be a result of only the host's temperament; it is also possible that it stems from the pre-established entertainment formula of the channel coupled with his limited financial means. Therefore, to ensure a friendlier and more relaxed character of the videos, they are enlivened using the means at the host's disposal. Such excessive use of extra- 
verbal communication results in relatively high opportunities in terms of image building.

Allow me to add that such a broad use of gesticulation and body language has its consequences: study subjects assigned not only positive ("charyzmatyczny" [charismatic], "pasjonat" [enthusiast], "ciekawie opowiada" [talks in an interesting manner], "pewny siebie" [confident]) or neutral characteristics ("o wyrazistej mowie ciała" [with an expressive body language], "wyluzowany" [chill]), but also some rather negative characteristics ("chaotyczny" [chaotic], "szalony" [mad], and "irytujący" [irritating]).

If one was to total the characteristics in the communication of which gesticulation as well as other aspects of body language played a part, such indications would constitute less than half of all the indications (46.1\%). If one considers the fact that extra-verbal communication communicates characteristics more often associated with the level of words rather than movements and looks, the share of gestures and, more broadly speaking, movements is very high in communicating one's image.

A question arises: can the set of the assigned characteristics be representative for everyone and in all conditions or maybe it is rather true for the Wojtek Drewniak's case? Or is it a feature typical of most YouTubers?

Surely, the very formula of the show requires specific conduct, yet there are other YouTubers with much more limited gesticulation than that of the discussed host, and those also include historians. ${ }^{22}$ Therefore, such a high share of gestures and other elements of body language could actually be specific for Wojtek Drewniak only.

To verify that, it would be necessary to analyse other historians in a new study. Interesting results could be offered by a comparison of the results presented in this article with the results of a study where study subjects would analyse only the tape scripts of the YouTuber's shows. That might help further filter the data and check which characteristics and to what extent may depend on body language and which on verbal elements to which it was more difficult to refer in the discussed study (the study subjects were not able to rewind a video and return to words or actions of the historian, unlike they would have been able in the case of reading a text).

Therefore, the communication of one's image using gestures is important for the image of Wojtek Drewniak. Gestures rarely exist in isolation as the bases for communicating individual characteristics. Many of the indicators of the discussed image-related characteristics included diverse extra-verbal aspects, and rarely verbal ones. The phenomenon analysed in this article may be of an individual nature, a fact which should be verified in new studies. 


\section{Bibliography}

Antas Jolanta, O kłamstwie i kłamaniu, Universitas, Krakow 2008.

Antas Jolanta, Kozień Michał, "Gesty i rytuały niewerbalne oraz ich znaczenie w obecnej polityce polskiej”, Acta Universitatis Lodziensis. Folia Litteraria Polonica 2018, issue 2(48), pp. 113-128.

Antas Jolanta, Załazińska Aneta, "Niewerbalne środki i strategie przekonywania stosowane w telewizyjnych debatach polityków", [in:] Sztuka perswazji. Socjologiczne, psychologiczne i lingwistyczne aspekty komunikowania perswazyjnego, eds. R. Garpiel, K. Leszczyńska, Wydawnictwo „Nomos”, Krakow 2008, pp. 183-194.

Babbie Earl, Badania społeczne w praktyce, Wydawnictwo Naukowe PWN, Warsaw 2004.

Boniecki Arkadiusz, "Pozajęzykowe środki kreowania wizerunku polityka”, [in:] Język w komunikacji, ed. G. Markowski, Wydawnictwo im. Stanisława Podobińskiego Akademii im. Jana Długosza w Częstochowie, Częstochowa 2011, pp. 31-42.

Caradec François, Dictionary of Gestures. Expressive Comportments and Movements in Use around the World, illustrated by P. Cousin, trans. Chris Clarke, The MIT Press, Cambridge, Massachusetts, London 2018.

Cienki Alan, Müller Cornelia, Metaphor and Gesture, John Benjamin Publishing Company, Amsterdam-Philadeplphia, 2010.

Fleischer Michael, „Rozsądny konstruktywizm”, [in:] Michael Fleischer, Ogólna teoria komunikacji, Wydawnictwo Uniwersytetu Wrocławskiego, Wrocław 2007, pp. 86-173.

Fleischer Michael, Typologia komunikacji, Primum Verbum, Łódź 2012.

Gajda Stanisław, “Teoria stylu i stylistyka”, [in:] Style współczesnej polszczyzny. Przewodnik po stylistyce polskiej, eds. E. Malinowska, J. Nocoń, U. Żydek-Bednarczuk, Universitas, Krakow 2013, pp. 15-33.

Gibbs Graham, Analizowanie danych jakościowych, trans. M. Brzozowska-Brywczyńska, series: Niezbędnik Badacza, Warsaw 2011.

Grove Theodore G., "Niewerbalne elementy interakcji”, [in:] Mosty zamiast murów. Podręcznik komunikacji interpersonalnej, ed. J. Steward, trans. J. Suchecki, P. Kostyło, J. Kowalczewska et al., 4th ed., Wydawnictwo Naukowe PWN, Warsaw 2005, pp. 122-134.

Íñigo-Mora Isabel, Álvarez-Benito Gloria, "Gestures and words in political discourse: a case study of the Obama-McCain encounter", Respectus Philologicus 2010, issue 18(23), pp. 11-25.

Jarząbek Krystyna, Słownik mowy ciała Polaków, Wydawnictwo Uniwersytetu Śląskiego, Katowice 2016. 
Komendarczyk Agnieszka, "Pozawerbalna ekspresja polityków w debacie telewizyjnej”, [in:] Język w komunikacji, ed. G. Markowski, Wydawnictwo im. Stanisława Podobińskiego Akademii im. Jana Długosza w Częstochowie, Częstochowa 2011, pp. 43-53.

Leathers Dale G., "Rozmowa kwalifikacyjna", [in:] Komunikacja niewerbalna. Zasady i zastosowania, przeł. M. Trzcińska, (ed. scientific) Z. Nęcki, Wydawnictwo Naukowe PWN, Warszawa 2009, pp. 345-352.

Leathers Dale G., "Wykrywanie oszustwa", [in:] Komunikacja niewerbalna. Zasady i zastosowania, trans. M. Trzcińska, ed. Z. Nęcki, Wydawnictwo Naukowe PWN, Warsaw 2009, pp. 299-324.

Leathers Dale G., "Zarzadzanie wrażeniem w praktyce", [in:] Komunikacja niewerbalna. Zasady i zastosowania, przeł. M. Trzcińska, (ed. scientific) Z. Nęcki, Wydawnictwo Naukowe PWN, Warszawa 2009, pp. 254-264.

Majkowska Aneta, "O komunikowaniu parawerbalnym i niewerbalnym w dyskusji sejmowej”, [in:] Język w komunikacji, ed. G. Markowski, Wydawnictwo im. Stanisława Podobińskiego Akademii im. Jana Długosza w Częstochowie, Częstochowa 2011, pp. 21-29.

Rossini Nicla, Reinterpreting Gestures as Language. Language "in Action”, IOS Press, Amsterdam-Berlin-Tokyo-Washington DC 2012.

Sikorski Wiesław, "Gesty kłamstwa", [in:] Wiesław Sikorski, Niewerbalna komunikacja interpersonalna. Doskonalenie przez trening, 2nd ed., Difin, Warsaw 2018, pp. 204-212.

Sikorski Wiesław, "Komunikacja niewerbalna podczas rozmowy kwalifikacyjnej", [in:] Wiesław Sikorski, Niewerbalna komunikacja interpersonalna. Doskonalenie przez trening, 2nd ed., Difin, Warsaw 2018, pp. 128-156.

Sikorski Wiesław, "Tworzenie pozytywnego wrażenia w polityce", [in:] Wiesław Sikorski, Niewerbalna komunikacja interpersonalna. Doskonalenie przez trening, 2nd ed., Difin, Warszawa 2018, pp. 156-185.

Szczepaniak Agnieszka, Gesty emblematyczne w międzykulturowej komunikacji niewerbalnej. Polsko-grecko-brytyjskie studium porównawcze i gestownik, Kaliskie Towarzystwo Przyjaciół Nauki, Uniwersytet Wrocławski, SWPS Uniwersytet Humanistyczno-Społeczny, Kalisz-Wrocław 2017.

Szymczyk Jan, "Funkcje mowy ciała w procesie kreowania wizerunku publicznego polityków”, Roczniki Nauk Społecznych 2018, vol. 10(46), no. 2, pp. 131-161, https://doi.org/10.18290/rns.2018.46.2-7A 


\section{Anna Barańska-Szmitko}

\section{Wizerunkowy sens energicznej gestykulacji youtubera. Przykład Wojtka Drewniaka z Historii bez cenzury}

Streszczenie

Celem artykułu jest zweryfikowanie, jakie znaczenie wizerunkowe ma gestykulacja w dyskursie popularnonaukowym na przykładzie filmów historyka Wojciecha Drewniaka, umieszczanych w serwisie YouTube. Posłużono się formułą eksperymentu, w którym uczestnicy badania oglądali film, by potem określić cechy wizerunkowe youtubera, a następnie wypisać, co stało się podstawą wyłonienia poszczególnych cech. Gestykulacja stała się kluczowa dla konstrukcji takich cech wizerunkowych, jak: „energiczny”, „pasjonat”, „charyzmatyczny”, „o wyrazistej mowie ciała”, „ciekawie opowiada”, „chaotyczny”, „szalony”, ,irytujący”, „pewny siebie”, „wyluzowany”. Oprócz gestykulacji, duże znaczenie wizerunkowe ma także ton i tempo mówienia oraz ekspresywna mimika. Potrzebne są kolejne badania, by zweryfikować, na ile uzyskane wyniki są typowe dla tego typu komunikacji na YouTube, a na ile jest to specyficzne wyłącznie dla Wojciecha Drewniaka.

Słowa kluczowe: wizerunek, dyskurs popularnonaukowy, YouTube, mowa ciała, komunikacja wizerunkowa.

\section{The impact of a YouTuber's lively gesticulation on his image. The case of Wojtek Drewniak and his Historia bez cenzury}

Summary

The aim of the article is to verify the importance of gesticulation on one's image in the popular science discourse based on YouTube videos by Wojciech Drewniak, a historian. The study employed the formula of an experiment in which subjects watched a video and defined the image-related characteristics of the YouTuber, and then were asked to write on what bases they assigned 
individual characteristics. Gesticulation became key for the construction of such image-related characteristics as: "energiczny" (energetic), "pasjonat" (enthusiast), "charyzmatyczny" (charismatic), "o wyrazistej mowie ciała" (with expressive body language), "ciekawie opowiada" (talks in an interesting manner), "chaotyczny" (chaotic), "szalony" (mad), "irytujący" (irritating), "pewny siebie" (confident), and "wyluzowany" (chill). Apart from gesticulation also tone and the pace of talking as well as expressive facial expressions had a major significance. It is necessary to conduct other studies to check to what extent the achieved results are typical for this type of YouTube communication and to what extent they are specific for Wojciech Drewniak only.

Keywords: image, popular science discourse, YouTube, body language, image-related communication

Anna Barańska-Szmitko - Ph.D., employee of the Chair of Journalism and Social Communication, University of Lodz. In her academic work, she focusses on the verbally communicated image; she also studies the methodology of research into linguistic communication of image based on an interdisciplinary approach, which combines several different perspectives (monograph: Wizerunek felietonisty i sposoby jego werbalnego komunikowania (2019) [Images of columnists and the modes of communicating them verbally]). Most recently, she focussed on the image of historian YouTubers who create content within the popular science discourse. 